\title{
Revisit Technology Acceptance Model for Internet Banking (Case Study: Public Banking in Indonesia)
}

\author{
Sevenpri Candra \\ School of Business Management - Bina Nusantara University \\ Jl. K.H. Syahdan No.9 - Palmerah/Kemanggisan - Jakarta Barat 11480, Indonesia \\ scandra@binus.edu
}

\begin{abstract}
In nowadays business, online service in Internet Banking is a major concern for managing customer relationship but in the other side, there are several challenge should be face by bank when they implement this technology. By using technology acceptance model, this research was conducted through questionnaires that printed and handed directly to customer that using internet banking. From 100 respondents that fill in the questionnaires and after the data that gathered are done to analyses. From four variables that research, only perceive usefulness that give significant contribution to the intention customer to use internet banking, the rest of the variables like ease of use, risk and trust still not significant. Factor of ease of use become critical and also trust and risk for customer want to use this services, otherwise this service just only wasting time and financial. For future research this model can be expanded into private banking and with mix unit analyses.

Index Terms - Technology Acceptance Model, Internet Banking, Public Banking, TAM, e-Banking
\end{abstract}

\section{Introduction}

In nowadays business environment, services becoming one of factor to achieve success in competitive environment. This is not just for the company in consumer goods or manufacturing but also in financial institution especially banking. Competitive in banking is also very tight. Each banks should be managed their customer. One of their services to the customer is internet banking.

Internet banking is one of innovation for giving full service for their customer. But this service require knowledge of technology especially customer using internet technology. Most of banking in Indonesia is offered this. This research will be highlighting the response of customer that using internet banking especially in private banking in Indonesia.

\section{Literature Review}

Technology Acceptance Model (TAM) is the most model that recently use to explore the use of internet banking. The main value proposition of using TAM is the ability to describe how individual customer beliefs and attitudes relate towards using 'something', in this case Internet Banking and whether or not the system will be used as intended [1], [2].

TAM focuses on attitudes toward the use of information technology by the user by adding to the perception of benefits and ease of use of information technology. TAM is an influential research models in studies of determinants of acceptance of information technology[3]-[6]. TAM is widely used to predict the level of user acceptance and usage, based on the relationship between information technology acceptance and its impact on individual users
The ease of use perceptions of information technology is the dominant factor to explain the perception of the benefits and use of a system. Utilization of technology related to the behavior of using the technology to complete the task. Utilization of information technology is that the benefits expected by users of information systems in performing their duties, the measurement is based on the intensity of use, frequency of use, and the number of applications or software used. In this study, the risk variables and confidence are also added to get more different result in the interest of customers that using Internet Banking.[2], [7]-[10]

\section{Research Method}

Based on literature review, the proposed model is developed[2], [7], [9], [11]-[13]. The research model can be seen in Figure 1.

Unit analysis are customer that using internet banking in private banking. By using convenience sampling, there are 100 respondents that fill the questionnaire. The questionnaire is developed by using Bahasa Indonesia and delivered direct to respondents using printed questionnaire.

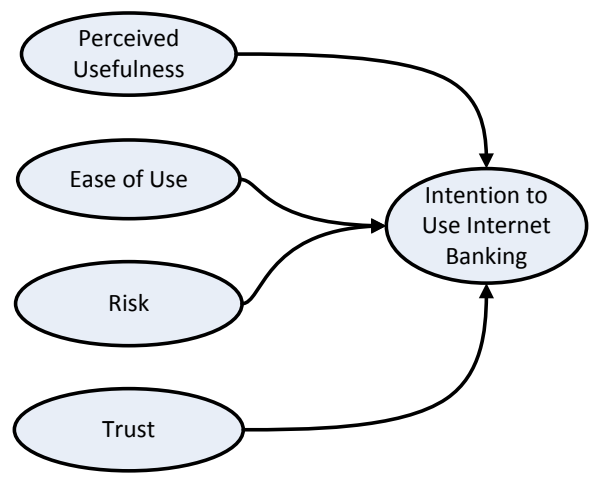

Figure 1. Research Model

\section{Research Finding}

Based on data and research model, the model is suitable to analysis by WarpPLS [14], [15]. There are two processes that will be done by WarpPLS, measurement model and structural model. As seen on Figure 2. Perceived Usefulness result giving significant influence to intention customer use internet banking. But others did not give any significant contribution. But the structural model test giving conclusion that the 
research model is fit and can be used for giving solution for this study (see Table 1).

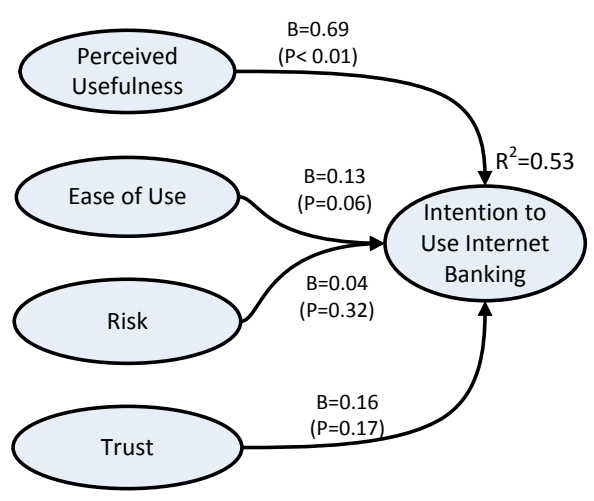

Figure 2. Result Model

Table 1. Model fit indices and P values

\begin{tabular}{|c|}
\hline $\mathrm{APC}=0.257, \mathrm{P}<0.001$ \\
\hline $\mathrm{ARS}=0.532, \mathrm{P}<0.001$ \\
\hline $\mathrm{AVIF}=1.101$, Good if $<5$ \\
\hline
\end{tabular}

\section{Conclusion}

Basically, from this finding can be concluded that user or customer that using internet banking still having problem of ease of use or user friendly services in internet banking online services. And also risk and trust still become a nightmare for customer or user. This also similar with other studies in another country, that this two problem always arise when using technology. This model can be expanded by using several unit analyses not only from the customer that using internet banking in public banking but also in private banking. Is there any different problem that their facing with this online services? Beside with different customer in different ownership, the next research also can be implemented by using clustering sample by using several control variables like education, ages, and sex. The finding of this research can be explaining the mapping of behavior of customer that using internet banking in each control variables.

\section{References}

[1] M. S. M. Ariff, S. M. Yeow, N. Zakuan, A. Jusoh, and A. Z. Bahari, "The Effects of Computer Self-Efficacy and Technology Acceptance Model on Behavioral Intention in Internet Banking Systems," Procedia Social and Behavioral Sciences, vol. 57, no. 0, pp. 448-452, Oct. 2012.

[2] C. S. Yiu, K. Grant, and D. Edgar, "Factors affecting the adoption of Internet Banking in Hong Kong--implications for the banking sector," International Journal of Information Management, vol. 27, no. 5, pp. 336-351, Oct. 2007.

[3] W. Read, N. Robertson, and L. McQuilken, "A novel romance: The Technology Acceptance Model with emotional attachment," Australasian Marketing Journal (AMJ), vol. 19, no. 4, pp. 223-229, Nov. 2011.

[4] C. H. Hsiao and C. Yang, "The intellectual development of the technology acceptance model: A co-citation analysis," International Journal of Information Management, vol. 31, no. 2, pp. 128-136, Apr. 2011.

[5] P. Legris, J. Ingham, and P. Collerette, "Why do people use information technology? A critical review of the technology acceptance model," Information \& Management, vol. 40, no. 3, pp. 191-204, Jan. 2003.

[6] F.-Y. Pai and K.-I. Huang, "Applying the Technology Acceptance Model to the introduction of healthcare information systems," Technological Forecasting and Social Change, vol. 78, no. 4, pp. 650660, May 2011.

[7] O. M. Karatepe, U. Yavas, and E. Babakus, "Measuring service quality of banks: Scale development and validation," Journal of Retailing and Consumer Services, vol. 12, no. 5, pp. 373-383, Sep. 2005.

[8] R. G. Kumar, G. Rejikumar, and D. S. Ravindran, "An Empirical Study on Service Quality Perceptions and Continuance Intention in Mobile Banking Context in India," Journal of Internet Banking and Commerce, vol. 17, no. 1, pp. 1-22, Apr. 2012.

[9] M. E. Malik, B. Naeem, and Z. Arif, "Impact of Perceived Service Quality on Banking Customers' Loyalty," Interdisciplinary Journal of Contemporary Research In Business, vol. 3, no. 8, pp. 637-645, Dec. 2011.

[10] R. Michel, N. J. Ashill, J. Shao, and J. Carruthers, "An examination of the relationship between service quality dimensions, overall internet banking service quality and customer satisfaction: A New Zealand study," Marketing Intelligence \& Planning, vol. 27, no. 1, pp. 103-126, 2009.

[11] W. D. Cook, L. M. Seiford, and J. Zhu, "Models for performance benchmarking: measuring the effect of e-business activities on banking performance," Omega, vol. 32, no. 4, pp. 313-322, Aug. 2004.

[12] B. Suh and I. Han, "Effect of trust on customer acceptance of Internet banking," Electronic Commerce Research and Applications, vol. 1, no. 3-4, pp. 247-263, 2002.

[13] M. Reid, "Integrating trust and computer self-efficacy into the Technology Acceptance Model: Their impact on customers' use of banking information systems in Jamaica," Ph.D., Nova Southeastern University, United States -- Florida, 2009.

[14] N. Kock, "Using WarpPLS in e-collaboration studies: An overview of five main analysis steps," International Journal of e-Collaboration (IJeC), vol. 6, no. 4, pp. 1-11, 2010.

[15] N. Kock, "Using WarpPLS in e-Collaboration studies:Descriptive Statistics, Settings, and Key Analysis Results," International Journal of e-Collaboration (IJeC), vol. 7, no. 2, pp. 1-18, Jun. 2011. 